\title{
Analysis of Mathematical Creative Thinking Ability of Junior High School Students on Angle Materials
}

\author{
Bahagia Bahagia $^{1,}$ Rahmah Johar ${ }^{1, *}$ Anwar Anwar ${ }^{1}$ \\ ${ }^{1}$ Department of Mathematics Education, Faculty of Teacher Training and Education, Universitas Syiah Kuala, \\ Indonesia \\ *Corresponding author. Email: rahmah.johar@unsyiah.ac.id
}

\begin{abstract}
Creative thinking is an important ability in mathematics, but the studies that have analyzed students' creative thinking abilities on angle material are still limited. This study aims to determine the mathematical creative thinking ability of junior high school students on angle material. The type of this research is quantitative. The instrument used in this work is mathematical creative thinking ability test, questions in the form of a description test are given to $7^{\text {th }}$ grade students in one of the junior high schools in Jantho City, Aceh Besar. The results showed that students' creative thinking ability in the angle material were still low with an average percentage of all indicators is $26 \%$, where the percentage of the fluency indicator was $36 \%$, the flexibility indicator was $42 \%$, the originality indicator was $22 \%$ and the lowest percentage was the elaboration indicator, which is $3 \%$. On the question of elaboration indicators, almost all students were not able to answer.
\end{abstract}

Keywords: Mathematical creative thinking ability, Creative thinking, Angle material.

\section{INTRODUCTION}

Creativity is an activity that will produce something useful and new [1]. New is something that doesn't exist yet, interesting, innovative, and can facilitate problem solving to raise better results. One of the steps to improve students' ability to think creatively is to design learning and provide opportunities for students to explore their knowledge [2]. Creative thinking is very necessary and useful for responding to the responses received and finding solutions to the problems faced. Problems will not always be able to be resolved with previously owned solutions, sometimes problems require new combinations, both in the form of attitudes, ideas, and solutions to solve them [3].

Creative thinking is an important ability that must be possessed by someone. Mathematics learning emphasizes that students need to have high-order thinking abilities to be developed in students, one of which is the ability to think creatively [4]. The ability to think creatively plays an important role in the daily life of students. Learning should be able to make students develop attitudes and thinking abilities so as to help them to deal with problems creatively [5]. Students with creative thinking abilities can solve problems in more than one way and use non-routine methods [6]. Thus, students have high originality. The development of creative thinking abilities is an important thing to be developed and needs to be trained on students at every level of education [7-8].

Facing the development of science, technology is very necessary to help the ability to think creatively considering the demands of technology-based learning [9]. In addition, higher order thinking abilities are needed to find various solutions to the problems [10]. Learning that provides concepts and formulas will be meaningless because it is rote, but discovery-centered learning will indirectly train students to think creatively and think critically.

The components of creative thinking, namely: fluency, flexibility, originality, and elaboration [11]. Fluency is the ability to generate multiple questions. Flexibility is the ability to generate many ideas or thoughts. Originality is the ability to think about something new or unique. Elaboration is the ability to examine objects, ideas, or situations in detail. The four aspects generally used to measure creative thinking ability. Students are said to be able to think creatively if they show the characteristics or components. 
One of the materials taught in junior high school mathematics is angle material. Angle is commonly found in everyday life, for example, angles on roofs of houses, angles on clock hands, tables, chairs, and so on [13]. Angle material is very important to learn because is widely used in many fields, for example in the fields of transportation, carpentry, and others [12]. In addition, it is also a prerequisite material in proving formulas in the plane material. According to [14] in studying angle material, it is necessary to have the ability to think in understanding advance concepts, procedures, principles. Based on the importance of creative thinking abilities and angle material, this study aims to determine how the mathematical creative thinking ability of junior high school students in angle material.

\section{METHODS}

The type of this research is quantitative descriptive. This method used to describe the conditions that occurred during the research [15]. The participants in this study were 31 seventh grade students who were randomly selected in one of the junior high schools in the city of Jantho. The time of this research was carried out in the even semester of the 2020/2021 school year. The instrument is a description test question which consists of two test questions for mathematical creative thinking abilities in angle materials.

Data analysis in this study used the percentage of student responses to questions in terms of fluency, flexibility, originality, and elaboration according to the modified rubric from [16]. The percentage of student responses to questions in each aspect is calculated by Equation (1).

percentage on score $i=$

$\frac{\text { the number of students on the score }}{31} \times 100 \%$

The percentage of each indicator is seen from the average response percentage on a maximum score. While the percentage of creative thinking ability is seen from the average percentage of all indicators.

\section{RESULTS AND DISCUSSION}

The fluency indicator of 31 students can be seen in Table 1. Question 1, there were no students who did not give an answer or gave an irrelevant idea and no one students who did not give an answer or gave an irrelevant idea, but there were two students who gave an idea that was relevant and the solution was complete and clear, 18 students gave more than one relevant idea but the solution is not clear and 11 students give more than one relevant idea and the solution was complete and clear. So that, the fluency indicator in question 1 has a percentage of $36 \%$. On question 2, there were no students who did not give answers or gave an irrelevant idea, but there was one student who gave a relevant idea but the solution was not clear, eight students gave a relevant idea and the solution was complete and clear, 11 students gave more than one relevant idea but the solution was less clear and 11 students gave more than one relevant idea and the solution was complete and clear. So that, the percentage of fluency indicator in question 2 is 36\%. Thus, the average percentage of student responses to the fluency

Table 1. Indicator of Description of Fluency

\begin{tabular}{|c|c|c|c|}
\hline \multirow{4}{*}{$\begin{array}{c}\text { Measured } \\
\text { Aspect }\end{array}$} & Score & $\begin{array}{r}\text { Many } \\
\text { Students }\end{array}$ & $\begin{array}{c}\text { Percentage } \\
(\%)\end{array}$ \\
\cline { 2 - 4 } & \multicolumn{3}{|c|}{ Question Number 1} \\
\hline \multirow{5}{*}{ Fluency } & 0 & 0 & $0 \%$ \\
\cline { 2 - 4 } & 1 & 0 & $0 \%$ \\
\cline { 2 - 4 } & 2 & 2 & $6 \%$ \\
\cline { 2 - 4 } & 3 & 18 & $58 \%$ \\
\cline { 2 - 4 } & 4 & 11 & $36 \%$ \\
\cline { 2 - 4 } & 0 & 0 & $0 \%$ \\
\cline { 2 - 4 } & 1 & 1 & $3 \%$ \\
\cline { 2 - 4 } & 2 & 8 & $26 \%$ \\
\cline { 2 - 4 } & 3 & 11 & $36 \%$ \\
\cline { 2 - 4 } & 4 & 11 & $36 \%$ \\
\hline
\end{tabular}

indicator is $36 \%$.

The flexibility indicator can be seen in Table 2 . On question 1, there were no students who did not answer the question, students who gave answers in one or more ways but incorrect were one student, seven students gave answers in more than one way with incorrect process and results, eight students gave answers in more than one way (various) but wrong results because there are errors in the calculation process, and 15 students gave answers in more than one way (various) with the right calculation process and the results. So that, the flexibility in question 1 has a percentage of $48 \%$. In question 2, there were no students who did not give answers, two students gave answers in one way or more but wrong answers, students who gave answers in more than one way with incorrect process and results as many as 11 students, seven students gave answers in more than one way (various) but the results were wrong because of errors in the calculation process, and 11 students gave answers in more than one way (various) with the correct calculation process and results. So that, Table 2 shows the percentage of flexibility indicator in question 2 is $36 \%$. So, the average percentage of student responses on the flexibility indicator is $42 \%$. 
Table 2. Indicator of Description of Flexibility

\begin{tabular}{|c|c|c|c|}
\hline \multirow{3}{*}{$\begin{array}{c}\text { Measured } \\
\text { Aspect }\end{array}$} & Score & $\begin{array}{c}\text { Many } \\
\text { Students }\end{array}$ & $\begin{array}{c}\text { Percentage } \\
(\%)\end{array}$ \\
\cline { 2 - 4 } & \multicolumn{3}{|c|}{ Question Number 1} \\
\hline \multirow{5}{*}{ Flexibility } & 0 & 0 & $0 \%$ \\
\cline { 2 - 4 } & 1 & 1 & $3 \%$ \\
\cline { 2 - 4 } & 2 & 7 & $23 \%$ \\
\cline { 2 - 4 } & 3 & 8 & $26 \%$ \\
\cline { 2 - 4 } & 4 & 15 & $48 \%$ \\
\cline { 2 - 4 } & 0 & 0 & $0 \%$ \\
\cline { 2 - 4 } & 1 & 2 & $6 \%$ \\
\cline { 2 - 4 } & 2 & 11 & $36 \%$ \\
\cline { 2 - 4 } & 3 & 7 & $23 \%$ \\
\cline { 2 - 4 } & 4 & 11 & $36 \%$ \\
\hline
\end{tabular}

The originality indicator can be seen in Table 3 . In question 1, there were no students who did not give answers or gave wrong answers, there were no students who gave answers in their own way but could not be understood, 18 students gave answers in their own way which the calculation process can be understood but the information is not clear, 16 students gave answers in their own way with the correct calculations but the information is not clear and seven students gave answers in their own way with the correct calculations and results. So that, Table 3 shows the originality indicator with a percentage of $22 \%$. In question 2 , there were no students who did not give answers or gave wrong answers, eight students gave answers in their own way but could not be understood, seven students gave answers in their own way which the calculation process can be understood but the information is unclear. Nine students gave answers in their own way which the calculation is correct but the information is not clear, and seven students gave answers in their own way with the correct results. So that, Table 3 shows the originality indicator with a percentage of $22 \%$. Thus, the average percentage of student responses on the originality indicator is $22 \%$.
Table 3. Indicator of Description of Originality

\begin{tabular}{|l|l|l|l|}
\hline \multirow{4}{*}{$\begin{array}{l}\text { Measured } \\
\text { Aspect }\end{array}$} & Score & $\begin{array}{l}\text { Many } \\
\text { Students }\end{array}$ & $\begin{array}{l}\text { Percentage } \\
(\%)\end{array}$ \\
\cline { 2 - 4 } & \multicolumn{3}{|c|}{ Question Number 2} \\
\hline \multirow{5}{*}{ Originality } & 0 & 0 & 0 \\
\cline { 2 - 4 } & 1 & 8 & $26 \%$ \\
\cline { 2 - 4 } & 2 & 7 & $23 \%$ \\
\cline { 2 - 4 } & 3 & 9 & $29 \%$ \\
\cline { 2 - 4 } & 4 & 7 & $22 \%$ \\
\cline { 2 - 4 } & Question Number & 2 \\
\cline { 2 - 4 } & 0 & 0 & 0 \\
\cline { 2 - 4 } & 1 & 8 & $26 \%$ \\
\cline { 2 - 4 } & 2 & 7 & $23 \%$ \\
\hline & 3 & 9 & $29 \%$ \\
\hline & 4 & 7 & $22 \%$ \\
\hline
\end{tabular}

The elaboration indicator of 31 students can be seen in Table 4. In question 1, nine students did not give answers or gave wrong answers, one student gave error answers and were not details, 20 students gave errors answers and less details, there were no students who gave incorrect but details answers, and one student gave correct and detailed answers. So that, Table 4 shows that the percentage of elaboration indicator on question number 1 is $3 \%$. In question 2, nine students did not give answers or gave wrong answers, one student gave incorrect and not detail answers, 15 students gave incorrect and less detailed answers, five students gave incorrect but detail answers, and one student gave correct and detailed answers. So that, Table 4 showed the elaboration indicator on question number 2 with a percentage of $3 \%$. So, the average percentage of student responses to the elaboration indicator is $3 \%$.

Table 4. Indicator of Description of Elaboration

\begin{tabular}{|c|c|c|c|}
\hline \multirow{3}{*}{$\begin{array}{c}\text { Measured } \\
\text { Aspect }\end{array}$} & Score & $\begin{array}{c}\text { Many } \\
\text { Students }\end{array}$ & $\begin{array}{c}\text { Percentage } \\
(\%)\end{array}$ \\
\cline { 2 - 4 } & \multicolumn{3}{|c|}{ Question Number 1} \\
\hline \multirow{3}{*}{ Elaboration } & 0 & 9 & $29 \%$ \\
\cline { 2 - 4 } & 1 & 1 & $3 \%$ \\
\cline { 2 - 4 } & 2 & 20 & $65 \%$ \\
\cline { 2 - 4 } & 4 & 1 & $3 \%$ \\
\hline
\end{tabular}




\begin{tabular}{|c|c|c|c|}
\hline \multirow{3}{*}{$\begin{array}{c}\text { Measured } \\
\text { Aspect }\end{array}$} & Score & $\begin{array}{c}\text { Many } \\
\text { Students }\end{array}$ & $\begin{array}{c}\text { Percentage } \\
(\%)\end{array}$ \\
\cline { 2 - 4 } & \multicolumn{3}{|c|}{ Question Number 2 } \\
\hline \multirow{5}{*}{ Elaboration } & 0 & 9 & $29 \%$ \\
\cline { 2 - 4 } & 1 & 1 & $3 \%$ \\
\cline { 2 - 4 } & 2 & 15 & $48 \%$ \\
\cline { 2 - 4 } & 3 & 5 & $16 \%$ \\
\cline { 2 - 4 } & 4 & 1 & $3 \%$ \\
\hline
\end{tabular}

Looking at the average percentage of all indicators of $26 \%$, there is no indicator that exceeds $50 \%$. The highest average percentage is found in the flexibility indicator, which is $42 \%$. It can be said that the average creative thinking ability students are still not satisfied. Furthermore, each student's answer will be discussed on each indicator.

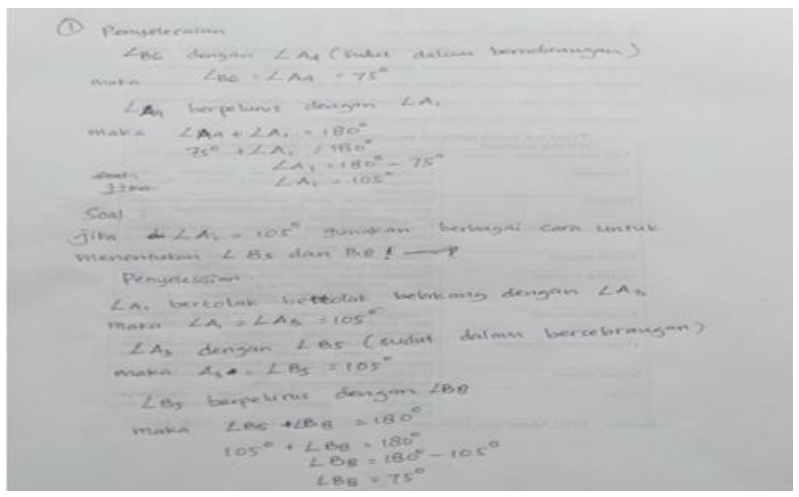

Figure 1 High-ability student's answer for question 1.

Figure 1 showed high-ability student's answer for question 1 . The student gave more than one relevant idea and the complete and clear solutions. In the indicator of fluency, the average percentage of students reaches $36 \%$, indicating that some students are able to answer questions correctly.

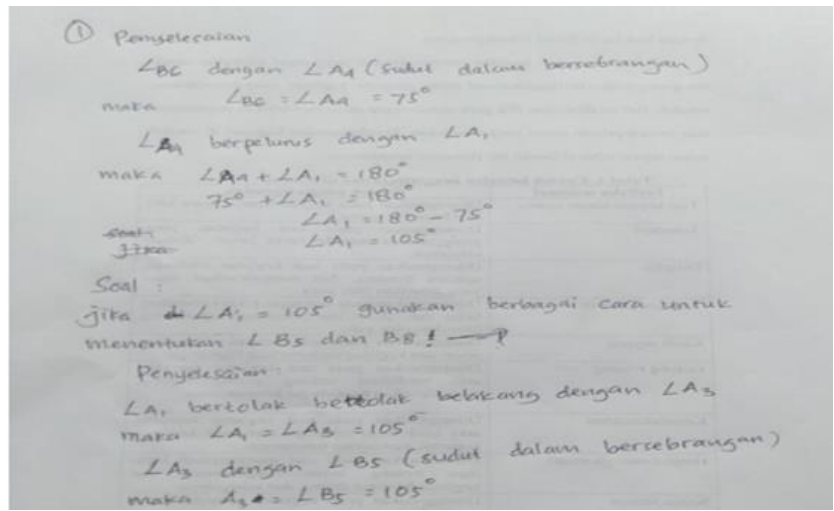

Figure 2 Moderate-ability student's answer for question 1 .

Figure 2 showed the moderate-ability student's answer for question 1. The student gave answers in his/her own way, the calculations were correct but the information was not clear. In originality indicator, the average percentage of students reached $22 \%$, indicating that some students were able to answer questions correctly.

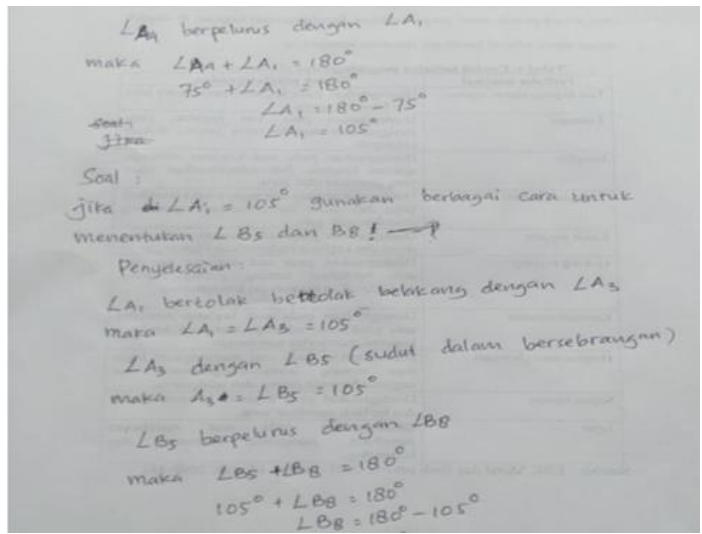

Figure 3 Low-ability student's answer for question 1.

Figure 3 showed low-ability student's answer for question 1. The student gave more than one relevant idea but the results are less clear. In the fluency indicator, the average percentage of students reaches $36 \%$, indicating that some students are able to answer questions correctly.

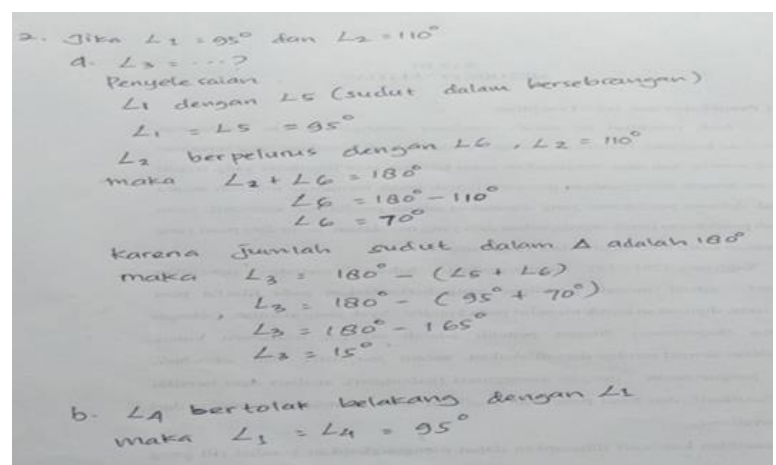

Figure 4 High-ability student's answer for question 2.

Figure 4 showed high-ability student's answer for question 2. The students have given answers in various ways, the calculation process and the results are correct. In the flexibility indicator, the average percentage of students reaches $42 \%$, indicating that some students are able to answer questions correctly. 


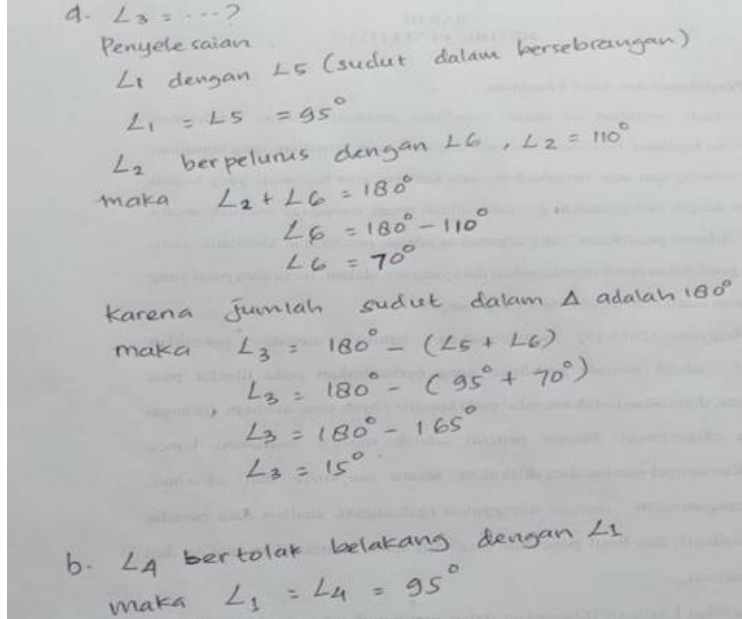

Figure 5 Moderate-ability student's answer on question 2.

Figure 5 showed moderate-ability student's answer on question 2. The student gave answer in various ways, the calculation process and the results are correct. The average percentage of students in flexibility indicator reaches $42 \%$, indicating that some students are able to answer questions correctly.

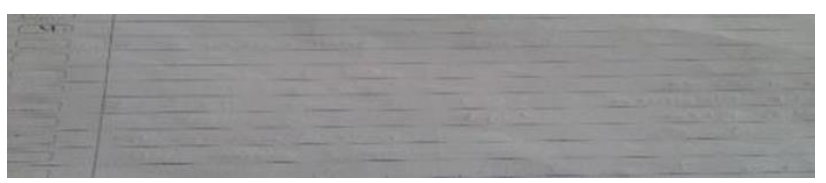

Figure 6 Low-ability student's answer for question 2.

Figure 6 showed low-ability student's answer for question 2. The students did not give answers. The average percentage of students for elaboration indicator, reaches $3 \%$, indicating that only one student was able to answer questions correctly.

From the results, it can be seen that students' mathematical creative thinking abilities are still relatively low with an average percentage of $26 \%$ for all indicators. The flexibility indicator gets the highest percentage, namely $42 \%$, while the fluency indicator is $36 \%$, the originality indicator is $22 \%$ and the lowest percentage is the elaboration indicator, which is $3 \%$. The results of this study are in line with previous research conducted by [17] where students' creative thinking abilities are still low. The elaboration indicator was being one of the indicators with the lowest percentage and the flexibility indicator was being the highest percentage.

In line with the results above, [18] suggested that the results of the analysis of the creative thinking ability of junior high school students are still relatively low, as can be seen from the number of errors made by students in solving mathematical creative thinking ability test questions. Meanwhile, according to [19], the creative thinking abilities of junior high school students are mostly in the criteria of being quite creative (medium).
These results indicate that the creative thinking ability of students in junior high school is still low and moderate.

The analysis above shows students' errors in solving problems of mathematical creative thinking abilities, it appears that students are less thorough in understanding the questions given, students only answer in one way and wrong in doing calculations. This shows that students are not accustomed to working on questions that train creative thinking abilities.

[20] states that the reality shows that students' creative thinking abilities are not optimal, the low creative thinking abilities of students are suspected because so far teachers have not tried to explore students' knowledge and understanding of creative thinking. To improve students' thinking abilities, it can be done by getting them used to working on questions that contain indicators of creative thinking [19]. Therefore, the teacher's role is very important in training students' mathematical creative thinking abilities.

\section{CONCLUSION}

Based on research in the angle material in Jantho City, the mathematical creative thinking ability of junior high school students is still very low with an average percentage of all indicators is $26 \%$. The flexibility indicator is the highest percentage, namely $42 \%$, indicating that some students are able to think flexibly in solving problems, the fluency indicator is $36 \%$, the originality indicator is $22 \%$ and the lowest percentage, namely the elaboration indicator, which is $3 \%$. On the elaboration indicator, only one student was able to answer correctly.

In improving students' mathematical creative thinking abilities, teachers should explore students' knowledge and understanding of creative thinking more and get them used to working on questions that contain indicators of creative thinking. It is also necessary to conduct further research on what learning is most appropriate to improve students' mathematical creative thinking abilities.

\section{AUTHORS' CONTRIBUTIONS}

All authors conceived and designed this study. All authors contributed to the process of revising the manuscript, and at the end all authors have approved the final version of this manuscript.

\section{REFERENCES}

[1] C. David, Mengembangkan Kreativitas, Kanisius, 1986.

[2] D.K. Fardah, Analisis proses dan kemampuan berpikir kreatif siswa dalam matematika melalui tugas open-ended, Jurnal Matematika Kreatif- 
Inovatif, 3(2) (2012) 91-99. DOI: https://doi.org/10.15294/kreano.v3i2.2616

[3] N. Fitriarosah, Pengembangan Instrumen Berpikir Kreatif Matematis untuk Siswa SMP, Prosiding Seminar Nasional Pendidikan Matematika 1, 2016, pp. 243-250.

[4] I.N. Dewi, P. Akbar, M. Afrilianto, Kemampuan Berpikir Kreatif Matematis Dan Disposisi Matematis Siswa Smp Melalui Pendekatan Kontekstual, Journal on Education 1(2) (2018) 279 287.

[5] A.R. Hutasuhut, Studi literatur meningkatkan kemampuan berpikir kreatif dengan pendekatan pmr matematis siswa, Journal of Mathematics Teacher Education 1(2019) 1-9.

[6] A.F. Rachman, R. Amelia, Analisis kemampuan berpikir kreatif matematis siswa SMA di kabupaten bandung barat dalam menyelesaikan soal pada materi trigonometri, MAJU: Jurnal Ilmiah Pendidikan Matematika 7(1) (2020).

[7] S.C. Dilla, W. Hidayat, E.E. Rohaeti, Faktor Gender dan Resiliensi dalam Pencapaian Kemampuan Berpikir Kreatif Matematis Siswa SMA, Journal of Medives 2(1) (2018) 129-136.

[8] W. Hidayat, Meningkatkan Kemampuan Berpikir Kritis dan Kreatif Matematik Siswa SMA Melalui Pembelajaran Kooperatif Think-Talk-Write (TTW), Seminar Nasional Penelitian, Pendidikan dan Penerapan MIPA (2012).

[9] M. Bernard, E.E. Rohaeti, Meningkatkan kemampuan penalaran dan disposisi matematik siswa melalui pembelajaran kontekstual berbantuan game Adobe Flash CS 4.0 (CTL-GAF), Edusentris, 3(1) (2016) 85-94.

[10] E.L. Rahayu, P. Akbar, M. Afrilianto, Pengaruh metode mind mapping terhadap strategi thinking aloud pair problem solving terhadap kemampuan berpikir kreatif matematis, Journal on Education, 1(2) (2019) 271-278.

[11] H. Hendriana, U. Sumarmo, Penilaian Pembelajaran Matematika Bandung PT Refika Aditama Komunikasi dan Representasi Matematis, Jurnal Pengajaran MIPA, 4(1) (2014) 6-9.

[12] N. Susilowati, Analisis Hambatan Berpikir Kritis Siswa dalam Menyelesaikan Soal Materi Garis dan Sudut Berdasarkan Teori Bruner (Doctoral dissertation, Fakultas Keguruan dan Ilmu Pendidikan UNISSULA) (2017).

[13] A. Ramadhani, R.C.I. Prahmana, Desain pembelajaran garis dan sudut menggunakan jam dinding lingkaran untuk siswa SMP kelas VII, Jurnal Review Pembelajaran Matematika, 4(2) (2019) 85-101.

[14] O.C. Suryanti, Identifikasi Berpikir Kritis dalam Pemecahan Masalah Matematika Pokok Bahasan Garis dan Sudut pada Siswa Kelas VII E SMP Negeri 4 Jember, 2015.

[15] N.S. Rahmawati, M. Bernard, P. Akbar, Analisis Kemampuan Komunikasi Matematik Siswa Smk Pada Materi Sistem Persamaan Linier Dua Variabel (SPLDV), Journal on Education, 1(2) (2019) 344352.

[16] Y. Oktaviani, Meningkatkan Kemampuan Berfikir Kreatif Matematik Siswa SMA yang Pembelajarannya Menggunakan Metode Tutor Sebaya. Skripsi Jurusan Pendidikan STKIP Siliwangi, Tidak diterbitkan, (2013).

[17] M.A. Andiyana, R. Maya, W. Hidayat, Analisis kemampuan berpikir kreatif matematis siswa smp pada materi bangun ruang, JPMI (Jurnal Pembelajaran Matematika Inovatif), 1(3) (2018) 239-248.

[18] T. Suparman, L.S. Zanthy, Analisis kemampuan beripikir kreatif matematis siswa SMP, Journal on Education 1(2) (2018) 503-508.

[19] H.D. Putra, A.M. Akhdiyat, E.P. Setiany, M. Andiarani, Kemampuan berpikir kreatif matematik siswa SMP di Cimahi, Jurnal Matematika KreatifInovatif 9(1) (2018) 47-53.

[20] A. Azhari, S. Somakim, Peningkatan kemampuan berpikir kreatif matematik siswa melalui pendekatan konstruktivisme di kelas VII sekolah menengah pertama (SMP) negeri 2 Banyuasin III, Jurnal Pendidikan Matematika 8(1) (2014) 1-12. 